\title{
Symmetric versus Asymmetric Rule
}

\section{Contrasting Views of the International Order}

\author{
Paul Robinson
}

\begin{abstract}
This article proposes that although both Russia and the West claim to support an international order founded on a mutually agreed set of rules, their views of that order are very different. For Russia it is a system in which the same set of rules applies to everybody, and which might therefore be termed "symmetric." For the West, it is a system in which those deemed "just" have more rights than those deemed "unjust," and which might therefore be termed "asymmetric." Through an analysis of recent trends in just war theory, the article will show that the asymmetric Western view of the international order is a natural outcome not only of the West's relative power but also of human rights doctrines. The supremacy of these doctrines is not, however, fully accepted by Russia. Overcoming Western-Russian tensions requires, among other things, that the two sides find a mutually acceptable view of the international order. The logic outlined in this article demonstrates, however, that this will be difficult to achieve.
\end{abstract}

Keywords: Russia, the West, international order, human rights, just war theory, double standards

\section{Paul Robinson}

Graduate School of Public and International Affairs, University of Ottawa, Canada.

Professor

Scopus AuthorID: 57205126860

E-mail: paul.robinson@uottawa.ca

Tel: +44 (613) 5625800 ext 4174

Address: 120 University, Ottawa, Ontario, K1N 6N5, Canada

DOI: $10.31278 / 1810-6374-2019-17-2-41-59$ 
belief that the international order is in crisis is widespread. For
many in the West, the problem is Russian aggression; for many
in Russia, it is the United States' determination to maintain its hegemony by any means possible. Yet what is meant by "international order" is not always clear. This article posits that Russian and Western leaders think of the international system very differently. In Russian eyes, it is an order in which the same set of rules applies to everybody; in Western eyes, it is a system in which one set of rules applies to the just and another to the unjust. For Russia, therefore, a rules-based international order is one which one might term "symmetrical"; for the West, it is one which is "asymmetrical."

Western states' asymmetrical understanding of international order makes them feel entitled to act in ways which they deny to others. This leaves them open to accusations of double standards. While scholars (e.g. Thakur, 2016 \& Turner, 2003) have previously drawn attention to the existence of such double standards-or as this article calls them, "asymmetrical rights"-a thorough analysis of how they are intellectually justified has not yet been conducted. Through an examination of the interaction between human rights doctrine and just war theory, this article will argue that the support by many in the West for an asymmetrical order is a logical outcome of human rights ideology as well as of the West's relative strength. Russian leaders do not necessarily accept that ideology. Russia is also relatively weak. These two factors explain Russia's preference for a symmetrical international system.

This article makes use of speeches and writings by politicians, diplomats, and prominent analysts of international affairs. While it can be argued that political utterances should not always be taken at face value, they are far from meaningless. Scholars of Critical Discourse Analysis have noted that political discourse is more than just rhetoric but also constitutes a form of action. As Norman Fairclough (2013: 400) writes, "Effective public sphere discourse is a constituent of action." Similarly, Ruth Wodak (2011, pp. 39-40) comments that "discourse constitutes situations ... It is constitutive both in the sense that it helps to sustain and reproduce the status quo, and in the sense 
that it contributes to transforming it." By participating in debates about the meaning of the international order, those cited in this article are not just engaging in rhetoric but are actively confirming or transforming the existing system. The differences between Russian and Western discourses on the international order are thus of considerable significance.

\section{DIFFERING VISIONS OF THE INTERNATIONAL ORDER}

In recent years, Russian leaders have been scathing in their accusations that Western states act in breach of international law. In January 2019, for instance, Russian President Vladimir Putin remarked that the crisis in Venezuela had been caused by a "destructive external interference that grossly violates the most basic norms of international law" (RT, 2019). Western leaders level similar charges against Russia. As former American Ambassador to the United Nations Samantha Power put it, "The Russian Government under President Putin is taking steps that are weakening the rules-based order ... under President Obama's leadership, we have shown our commitment to investing in and abiding by the rules-based order. The same cannot be said for the Russian Government today. For years, we have seen Russia take one destabilizing action after another" (Power, 2017).

From such statements it is clear that both Russia and the West claim to believe in an international order based on rules or law. However, each accuses the other of breaking those rules. Part of the problem may be that the two sides do not understand the rules in the same way. Indeed, Russia and the West do not always assign the same meaning to the vocabulary of international relations. As Andrew Monaghan comments in an examination of Russian-Western relations, "The problem of definition of terminology goes to the heart of the strategic dissonance" (Monagan, 2016, p. 75).

For instance, analysts in both Russia and the West accuse the other side of waging "hybrid war," but as Ofer Fridman has pointed out in a recent book, Russian and Western understandings of hybrid warfare are very different (Fridman, 2018). In another example, a few years ago Russia and the NATO countries reached an agreement that 
security in Europe should be considered “indivisible." But the two sides understood this completely differently. The Russians thought that this meant that NATO had agreed that European security had to encompass all of Europe including Russia, with no divisions in a geographical sense. NATO thought that Russia had agreed that security was indivisible in the sense that it should not be divided up into different types of security, such as military security and human security, and had therefore accepted the idea that human rights were an inseparable part of security. This mutual misunderstanding meant that subsequent discussions on the matter went nowhere (Monaghan, 2016, pp. 75-78).

In a newbook, Keir Giles of the Royal Institute of International Affairs (Chatham House) discusses another example of misunderstanding. Giles comments that the NATO-Russia Council created in 2002 failed to improve relations between the two parties because NATO considered that it was treating Russia as an "equal" by including it in the Council, but for Russia "equality with NATO ... means with the organization as a whole-not with individual states such as Luxembourg” (Giles, 2019). Discussing Russia's relationship with the European Union (EU), Giles then adds: "The failure of an EU offer of 'equality' similarly resulted from a different failure of understanding the word. The 'Four Common Spaces' initiative was intended to be an agreement of 'equal partners.' But the Russian interpretation of 'equality' was that both Moscow and Brussels would make reciprocal concessions and compromises, rather than Russia alone modifying its standards, procedures, and rules to get closer to Europe" (Giles, 2019).

This example reveals an important divergence in Russian and Western understandings of the international order. Bobo Lo notes that, "The EU has assumed a normative, as well as political and economic, monopoly of what it means to be European, while NATO has achieved much the same in the military and security spheres" (Lo, 2009, p. 2 ). For the EU and NATO, the international order is one in which there is only one set of correct "standards, procedures, and rules"their own. Equality does not mean acceptance of everybody's own standards as equally valid, or some compromise between them, but 
rather is achieved when everyone accepts the standards of the West. Membership in the order is thus restricted to those who abide by these standards. The order itself can be seen as something with the West at its core, which gradually expands out of the West as others integrate with it.

Western behaviour in the post-Cold War era has matched this conception of the international order. Rather than dismantling Cold War institutions and seeking a new international architecture which would incorporate other major powers (such as Russia and China) as equal partners, the West has retained those institutions (such as NATO) and expanded their reach, seeking to bring more and more nations within their orbit, either as members, allies, or "partners" (e.g. NATO's Partnership for Peace, and the EU's Eastern Partnership). Western leaders have thereby demonstrated that they view the international order first as an order based on Western "standards, procedures, and rules" (or as they are often called, "values"), and second, as an order that is Western-led.

The first of these visions is often associated with the phrases "liberal international order" and "rules-based international order." Canadian Foreign Minister Chrystia Freeland, for instance, regularly makes use of this terminology. In an August 2018 speech, she spoke of the "weakening of the international rules-based order," an order which she said was based on multilateral institutions and "shared values and standards-a commitment to pluralism, human rights and the rule of law" (Freeland, 2018).

Freeland represents what one might call the "liberal" trend in Western thinking. There is also a Realist trend, which is traditionally most pronounced in the United States. The latter trend is less enamored of multilateral institutions and rejects what it sees as the idealistic belief of liberal internationalists that order can be maintained through voluntary subordination to international law. Realists regard the world as fundamentally anarchic and in need of a hegemon who can enforce order. Since the United States is the current hegemon, what is good for the United States is thus good for the world. America is the "exceptional nation" and in its role as hegemon is not bound by the 
same rules as others. In Robert Kagan's words, “international order is not an evolution; it is an imposition. It is the domination of one vision over others" (Kagan, 2012). Americans thus often speak of the international order as "U.S.-led."

The advent of the "unipolar moment" in the 1990s provided an opportunity for these two visions to merge. The proponents of Western hegemony found that the Cold War victory of democracy and human rights provided a moral justification for maintaining a system in which the West acted as the enforcer of international order. The proponents of a liberal, values-based international system realized that the enormous military superiority of the West could be a useful means to extend their vision of human rights throughout the globe. Consequently, the end of the Cold War led to what Graham Allison calls "an odd coupling of neoconservative crusaders on the right and liberal interventionists on the left. Together, they persuaded a succession of U.S. presidents to try to advance the spread of capitalism and liberal democracy through the barrel of a gun" (Allison, 2018, p. 130). Today the conventional wisdom in Western corridors of power is a vision of the international system as one founded on values (human rights and democracy) but also one in which the enforcers of those values (the West), in their capacity as the system's leaders, enjoy certain privileges.

The West's vision reflects its relative power. Having enjoyed overwhelming military and financial power since the collapse of the Soviet Union, the West has favored a version of the international order which maximizes its ability to use its power. However, Russia, as a much weaker party, has favored an understanding of the international order which attempts to limit the use of power. As a state which feels excluded from the Western system, Russia also promotes a different order in which its interests will receive greater consideration. Russia's attitude can therefore be seen as "a measure of the asymmetry of power between it and the West” (Wood, 2018, p. 137).

Thus, although Russian leaders also emphasize the importance of international order, they define the idea differently. This reflects long-standing preferences. In the late 1980s, Soviet leader Mikhail Gorbachev complained of attempts to "exclude" the Soviet Union from 
Europe (Gorbachev, 1987, p. 191), and spoke of a "common European home" and of Europe "from the Atlantic to the Urals" (nowadays often rephrased even more expansively as "from Lisbon to Vladivostok") (Gorbachev, 1987, pp. 194, 197). Gorbachev firmly rejected the idea that European politics should be dominated by institutions which excluded the Soviet Union. But he by no means meant that the Soviet Union should abandon its own way of doing things and be absorbed within the institutions of the West. Instead, he argued for a European order which took the interests of all states equally into account, accepted the rights of different nations to "a social setup that suits them" (Gorbachev, 1987, pp. 212-213), and was founded on "constructive cooperation" (Gorbachev, 1987, p. 204).

Post-Soviet leaders have generally pursued similar objectives. A notable example was Dmitry Medvedev's 2008 proposal for a new treaty on European security. Medvedev stressed that, "no state or international organization can have exclusive rights to maintaining peace and stability" (Lo, 2009, p. 4). Arguing that none of the existing European security structures were all-inclusive, Medvedev proposed a new architecture which would include not only NATO and the EU, but also the Organization for Security and Cooperation in Europe (OSCE), the Collective Security Treaty Organization, and the Commonwealth of Independent States (CIS). The draft treaty was founded on the "principles of indivisible, equal, and undiminished security", and emphasized that any action taken by Parties to the treaty should be "implemented with due regard to security interests of all other Parties" (Layton, 2014, p. 26). Russia sought to move the discourse of European security away from "the perpetuation of outdated ideological conflict and bloc approaches which perpetuate exclusion, isolation and inequality in the security system" and towards the "values of inclusion and equality" (Layton, 2014, pp. 29, 40).

The treaty on European security foundered in the face of Western opposition, but Russia has continued to propose similar ideas. According to the 2016 Foreign Policy Concept of the Russian Federation: "The Russian Federation's foreign policy is aimed at creating a stable and sustainable system of international relations based on the generally 
accepted norms of international law and principles of equal rights, mutual respect and non-interference in domestic affairs of States, so as to ensure solid and equal security for each and every member of the global community" (The Ministry of Foreign Affairs, 2016). The document also notes that the Russian Federation aims "to ensure the respect for human rights and freedoms across the world through constructive and equal international dialogue with due regard for each State's national context, culture, history and values" (The Ministry of Foreign Affairs, 2016).

This formulation of international order is subtly but crucially different from the Western one. It emphasizes the need to respect cultural differences between states, and stresses national sovereignty and non-interference. In this view, all sovereign states are equal, and none have the right to impose their standards or values on others. Rights in the international order are symmetrical. By contrast, the Western view-in which membership in the international order is conditional on accepting Western values-suggests that states' rights are unequal and asymmetrical. However, the diverging views do not merely reflect the imbalance of power between Russia and the West. As the next section will show, they are also a product of ideological differences, in particular the priority given in the West to human rights thinking. When applied to the international order, this mode of thought logically produces a system based on asymmetry.

\section{THE JUSTIFICATION OF FORCE, HUMAN RIGHTS AND DOUBLE STANDARDS}

The differences between the Western and Russian perspectives on the international order are especially wide in matters relating to the use of force, in particular attempts by Western powers to enact regime change in foreign countries or to engage in military humanitarian interventions. A turning point in this regard was the 2001 report of the International Commission on Intervention and State Sovereignty-an initiative of the Canadian government. The report introduced the idea of a "responsibility to protect," and concluded that, "Where a population is suffering serious harm ... the principle of non-intervention yields to 
the international responsibility to protect" (International Commission, 2001, p. xi).

The report listed various principles which should guide states in determining whether to invoke the responsibility to protect: just cause, right intention, last resort, proportional means, reasonable prospects, and right authority (International Commission, 2001, pp. xii-xiii). These criteria were not the creations of the International Commission, but were taken straight out of just war theory, which lays down rules for when force may be used (jus ad bellum) and for what actions are permitted during wars (jus in bello). There are two major ways of looking at just war theory. The first considers it to be founded on a "presumption against war." In this view, the default position is that military action is prohibited, and anybody wishing to use force must prove that they have met all the criteria of just war theory (just case, right intention, etc.). The second way of looking at the theory is to see its fundamental principle as being "the presumption is to restrain evil and protect the innocent." In other words, the pursuit of justice is considered more important than the absence of war. According to the first view, just war theory is restrictive-it serves to limit war; according to the second, it is permissive-it originally arose out of a need to overcome religious constraints on the use of force (Robinson, 2012, p. 182).

In reality, just war theory is not so much a theory as a mish-mash of moral principles which have accumulated over centuries and which together provide a framework within which the morality of war may be discussed. The various criteria reflect numerous different ways of looking at moral problems-deontology, utilitarianism, virtue ethics, and so on. The criteria are all generally considered to be of equal value.

During the Cold War, the philosophical trend in the West was towards more restrictive interpretations of just war theory, in large part due to fear of a third world war and perhaps even nuclear war. There was therefore a strong tendency to embrace a "presumption against war" and to argue that all of the just war criteria had to be met before military action could be justified, and that all the criteria were therefore of equal value. This understanding of the rules of the 
international order was essentially rule-consequentialist-fear of negative consequences led to the establishment of highly restrictive rules.

The end of the Cold War and the rise of human rights thinking led many in the West to abandon rule-consequentialism and instead develop a more permissive attitude towards the use of force. Rightsbased reasoning has largely shunted aside the other types of moral thought which were previously combined in just war theory, such as consequentialism. Confident that military action is no longer likely to escalate into a broader global conflict, the West (as shown by the report on the responsibility to protect) has reinterpreted just war theory so as to place just cause (specifically the defence of human rights) above other criteria and to state that this cause takes priority over the avoidance of war.

This rewriting of the rules of the international order is a source of perception of double standards. Russia and other non-Western states largely continue to view the idea of a rules-based order in terms of the older rule-consequentialist idea which insists upon symmetry in the application of rules. By contrast, the West's newly favored rights-based reasoning permits asymmetry.

This can be seen through an examination of how human rights thinking has affected two key concepts within just war theory-the jus in bello/ad bellum divide and the moral equality of soldiers. The first of these refers to the concept that the rules which determine whether one may wage war at all, jus ad bellum, are entirely distinct from the rules which determine what one may do during a war, jus in bello. Whether one's war is just or unjust, one must still follow the same jus in bello rules.

Because jus in bello was traditionally seen as distinct from jus ad bellum, it followed that individual soldiers were not morally or legally responsible for the wars they fought, in other words for ad bellum, but only for their conduct during war, in bello. This meant that soldiers on both sides were considered morally equal. To give an example, in the American Civil War the Confederacy was fighting for a demonstrably unjust cause-the defence of slavery. Nevertheless, Confederate 
soldiers were still considered moral equals of their Union counterparts. The Union soldier had the right to shoot at the Confederate soldier; but the Confederate soldier also had the right to shoot at the Union soldier. As long as Confederates just shot at other soldiers, they were not considered to have broken any rules or to have behaved morally incorrectly. The fact that they were fighting for an unjust cause did not affect their personal moral status. On the other side, the fact that Union soldiers were fighting for what most people would consider a more noble cause-preservation of the Union and the abolition of slavery-did not permit them to do anything they pleased. They too could only shoot at soldiers.

There is a good reason for this. If you have asymmetrical rules, and you say that jus in bello is dependent upon jus ad bellum, so that different rules apply to the just side as opposed to the unjust side, then who is to say who is the just side? Everyone will claim to be the just side, and probably believe themselves to be such. They will therefore claim the extra rights which come with that, while denying any rights to the other side. Consequently, mutual respect will collapse, and there will be no sense of reciprocity and no incentive to abide by rules. Restraint will become much harder. Harsh experience has shown that it is necessary to treat each side as equal, because that is the only way to get them to abide by the rules. The logic here is essentially rule-consequentialist. We create a rule of symmetry, because a rule of asymmetry produces terrible consequences.

This rule-consequentialist logic is the traditional way at looking at the rules of armed conflict. Writing in the sixteenth century, Spanish jurist Francisco de Vitoria noted that a war could not be just on both sides. Nevertheless, both sides might consider themselves just, and given the limitations on human knowledge, might even be excused for considering themselves such (Reichberg, Syse and Begby, 2006, p. 322). This established the principle of "simultaneous ostensible justice"-regardless of who objectively has right on their side, we treat all parties as equals. As German philosopher Christian von Wolff put it, "since no nation can assume for itself the function of a judge, and consequently cannot pronounce on the justice of the war ... the war 
must be considered as just on both sides" (Reichberg, Syse and Begby, 2006, p. 474). In a book on international law, eighteenth century Swiss jurist Emer de Vattel added another reason for this conclusion, arguing that, "Nations ... are by nature equal and hold by nature the same obligations and the same rights" (Reichberg, Syse and Begby, 2006, p. 506).

This was the prevailing view until recently. In the past few decades, however, a fundamental re-evaluation of just war theory undertaken by some Western philosophers has reworked the rules of war on the basis of individual human rights. In the process, the idea of symmetrical rules has been abandoned in favor of asymmetry.

One of the most notable examples is the 2009 book Killing in War by Jeff McMahan of Rutgers University. McMahan begins by asking why people are allowed to kill other people in war. From a human rights perspective, everybody has a right to life. The only justification for killing people, therefore, is that they have done something to forfeit that right. So what have they done? The usual answer is that they are engaged in harming others, if not directly then at least as part of a large apparatus which is engaged in harming others. Because they are doing harm, they forfeit their right to life. Therefore, you can kill them. This is nonsense, says McMahan. If I hit you for no good reason, and then you hit me back, you do not then lose your right not to be hit by me again. Similarly, if a policeman shoots an armed criminal, the policeman does not lose his right not to be shot by the criminal. That is because he is serving a just cause, whereas the criminal is serving an unjust one. Rights, therefore, cannot be disassociated from issues of justice. The rights of the just are not the same as the rights of the unjust. There is an asymmetry of rights. McMahan notes that, "the morality of conflict is almost invariably asymmetric: those who are in the right may be permitted to use force and violence, but those who are in the wrong are not" (McMahan, 2008, p. 35). Consequently, jus in bello is in fact dependent on jus ad bellum, and there is no moral equality of combatants.

Taking this further, McMahan then argues that the unjust side loses most of its rights. It is not even allowed to shoot at other soldiers, 
as the soldiers on the just side have done nothing to forfeit their right to life. Thus, all soldiers on the unjust side are murderers, pure and simple. On the other hand, the just party gains extra rights. There are a host of people on the enemy side, including many civilians working in industries and offices supporting the war effort, who are in effect aiding and abetting the unjust cause. Since they bear moral responsibility for threatening the innocent, they forfeit their right not to be attacked. Thus, says McMahan, "the idea that civilians can in principle be liable to military attack is not intuitively implausible" (McMahan, 2008, p. 224). The result of this logic is that the unjust party may not even target the just party's soldiers, whereas the just party may target even the unjust party's civilians. So, whereas before one had a situation where the rights of both sides were level, now the rights of one have gone down, and those of the other gone up.

Oxford philosopher David Rodin takes a slightly different tack, accepting the first half of McMahan's thesis (that the unjust party loses rights) but not the second (that the just party gains rights). $\mathrm{He}$ therefore concludes that asymmetry is "half right" (Rodin, 2008, p. 4468). But although Rodin's position is slightly different from McMahan's, the result is still an asymmetrical system, in which those who are considered "just" have more rights than those who are considered "unjust."

These are not just philosophical musings. To some extent this is how the American-led Global War on Terror has been fought. When the Americans invaded Afghanistan, captured enemies were not treated as prisoners of war, but as criminals. Take, for instance, the case of Omar Khadr, whose parents took him to Afghanistan prior to the American invasion. He was 15 years old when he allegedly threw a grenade at an American soldier, killing him. This happened in the midst of combat. According to the traditional concept of the moral equality of soldiers, Khadr had a perfect right to throw the grenade after the Americans attacked the house in which he was living. But he was tried and convicted of murder. According to the new American interpretation of the law, the unjust side does not have the right to shoot back. 
McMahan and Rodin restrict themselves largely to issues of jus in bello, but human rights reasoning leads to the same conclusion of asymmetrical rights when considering jus ad bellum and state sovereignty. Canadian philosopher Brian Orend, for instance, argues that certain basic human rights are universally valid. A state which does not protect these rights has no right not to be attacked. This is because the human rights of individuals come before the political rights of states. As Orend puts it, "regimes which fail the conditions of minimal justice are not legitimate and thus have no state rights, including the right not to be attacked and overthrown" (Orend, 2006, p. 97). Following this logic, Orend comments that although invading Iraq may not have been the wisest move for the United States in 2003, "Saddam's regime had no right not to be attacked" (Orend, 2006, p. 97).

In this new conception of international order, de Vattel's statement that, "Nations ... are by nature equal and hold by nature the same obligations and the same rights" is no longer true. Those with power will be able to label others as not "minimally just" and so claim a right to take action against them, while also arguing that those others do not have a right to act in the same way. This helps to explain why many in the West find the theory attractive. It also explains why Russian leaders consider the West to be guilty of hypocrisy. For instance, in a 2017 speech, Vladimir Putin accused the West of double standards which, he said, "pose serious danger to the stable development of Europe and other continents" (Putin, 2017). Similarly, in November 2018 Foreign Minister Sergei Lavrov complained that Western states were breaking international law, and commented that, "They give us a glaring example of double standards” (TASS, 2018b).

Western leaders reject these accusations, claiming that they amount to "false equivalencies." Actions (such as military intervention or support for opposition groups in other countries) taken in the name of a just cause (democracy, human rights, etc.) cannot be considered equivalent to identical actions taken on behalf of an unjust cause. Samantha Power, for instance, remarks that, "We must also reject the false equivalency between the work that the U.S. Government and the 
Russian Government are doing in other countries. ... There is a world of difference between supporting free and fair elections, and investing in independent institutions that advance human rights, accountability, and transparency-as we do; and trying to sow distrust in democratic processes, misinform citizens, and swing elections towards illiberal policies as Russia is doing" (Power, 2017).

Similarly, Chrystia Freeland comments that, "One device strong men use to justify their rule is the Soviet trick of 'whataboutism'the strategy of false equivalency that holds that because democracies are inevitably imperfect they lack the moral authority to criticize authoritarian regimes. ... We need to resist this corrosive nonsense. We need to summon Yeats' oft-cited 'passionate intensity' in the fight for liberal democracy and international rules-based order that supports it" (Freeland, 2018).

But while both Power and Freeland reject the charge of double standards, they do not deny an asymmetry of rights in the new international order. As is clear from their speeches, they take the position that interference in the internal affairs of other states in the pursuit of "liberal democracy" is permitted, but interference in the pursuit of "illiberal policies" is not. Thus liberal states can interfere, but those deemed "illiberal" cannot.

According to the prevailing Western logic, what Russia calls "double standards" but which might more properly be called "asymmetrical rights," are not only permissible but even correct. The fact that there are double standards does not mean that this is not a rules-based system; it is merely a system which classifies states into two different categories (just and unjust) and applies different rules to each of them.

The focus on human rights in the West creates an asymmetrical system in which perceptions of justice and injustice determine what rules apply to whom. It is permissible for America to provide aid to rebels in Syria, because the regime of Bashar al-Assad is not a minimally just state and so has forfeited its right not to be attacked, and because the Americans are just, and so are entitled to act as world policemen. 
But it is wrong for Russia to provide aid to the Syrian government, because Russia is aiding an unjust state which abuses human rights. Similarly, if Russian bombs kill civilians in Aleppo, that is wrong, because it is in support of an unjust cause. But if American bombs kill civilians in Mosul, that is regrettable but acceptable, because it is in a just cause. What appears to be a double standard is a logical and probably inevitable consequence of basing moral judgements on human rights.

This conception of the international order creates many problems, one of which is that those who are classified as being in the unjust category are likely to reject it. It also helps to increase Russian-Western tensions because Russians for the most part do not appear to follow the same rights-based approach to moral reasoning. The Russian approach remains more traditional and in line with the rule-consequentialist logic. We thus end up with two protagonists saying that they want the same thing, but meaning very different things by it. When Russia says it supports a rules-based order, it means one in which the same rules apply to everybody. All states are sovereign and equal. When Western leaders say that they support a rules-based order, they have in mind one in which the morally just states (i.e. their own) enforce the rules, and are therefore rather like the police, while their enemies are rather like criminals. And as McMahan has pointed out, the police are allowed to shoot at the criminals whereas the criminals are not allowed to shoot back.

It is important to note that none of the above means that asymmetry is necessarily worse than the alternative. So far this article has focused on the problems associated with human rights reasoning, but the idea expressed by Vladimir Putin in a 2012 statement that "it is definitely true" that sovereignty takes precedence over human rights (Baranovsky and Mateiko, 2016, p. 52) is also problematic, especially if applied as an absolute rule. Rule-consequentialism can be frighteningly callous. It requires people to ignore injustice in order to abide by the rules. Part of the reason why human rights reasoning has become so prevalent in Western thinking on foreign affairs in the past 20 years is precisely that in the aftermath of the Rwandan genocide and the war in Yugoslavia 
many intellectuals felt that it was intolerable that the rules of the international system forbade interference.

The purpose of this article, therefore, is not to say that one view of affairs is better than the other, but merely to demonstrate that very different ideas of how the world should be governed constitute one of the misunderstandings which underlie current East-West tensions. If Russia and the West wish to improve relations, they must reach a common interpretation of the rules. This will not be easy. The contrasting views of the international order reflect both imbalances of power and ideological differences concerning the relative importance of human rights compared with other factors in international affairs. But while the task may be hard, it is worth the effort. Much may depend on whether agreement can be achieved.

\section{References}

Allison, G., 2018. The myth of the liberal order: from historical accident to conventional wisdom. Foreign Affairs, 97(4), pp. 124-133.

Baranovsky, V. and Mateiko, A., 2016. Responsibility to protect: Russia's approaches. The International Spectator, 51(2), pp. 49-69.

Fairclough, M., 2013. Critical discourse analysis: the critical study of language. London: Routledge.

Freeland, C., 2018. In defence of the rules-based international order: How Canada and its partners must fight back. IISS, 2 August. Available at: <https:// www.iiss.org/events/2018/08/canada-defence-rules-based-order-fullertonlecture $>$ [Accessed 14 February 2019].

Fridman, O., 2018. Russian hybrid warfare: resurgence and politicisation. London: Hurst.

Giles, K., 2019. Moscow rules: what drives Russia to confront the West. Washington, D.C.: Brookings.

Gorbachev, M., 1987. Perestroika: new thinking for our country and the world. London: Collins.

International Commission on Intervention and State Sovereignty, 2001. The responsibility to protect. Ottawa: International Development Research Centre. 
Kagan, R., 2012. Why the world needs America. Brookings, 11 February. Available at: <https://www.brookings.edu/articles/why-the-world-needsamerica/> [Accessed 14 February 2019].

Layton, S., 2014. Reframing European security: Russia’s proposal for a new European security architecture. International Relations, 28(1), pp. 25-46.

Lo. B., 2009. Medvedev and the new European security architecture. Centre for European Reform Policy Brief. Available at: <https://www.cer.eu/sites/default/ files/publications/attachments/pdf/2011/pbrief_medvedev_july09-741.pdf> [Accessed 22 February 2019].

McMahan, J., 2009. Killing in war. Oxford: Oxford University Press.

Monaghan, A., 2016. The new politics of Russia: interpreting change. Manchester: Manchester University Press.

Orend, B., 2006. The morality of war. Peterborough, Ontario: Broadview.

Power, S., 2017. Russia: the threat, the international order, and the way forward. US Embassy and Consulates in Russia, 17 January. Available at: <https:// ru.usembassy.gov/remarks-ambassador-samantha-power-russia-threatinternational-order-way-forward/> [Accessed 14 February 2019].

Putin, V., 2017. Meeting of the Valdai International Discussion Club. Kremlin.ru, 19 October. Available at: <http://en.kremlin.ru/events/president/news/55882> [Accessed 15 February 2019].

Reichberg, G., Syse, H. and Begby, E., 2006. The ethics of war: classic and contemporary readings. Oxford: Blackwell.

Robinson, P., 2012. Just war theory: yesterday, today, and tomorrow. In: Lee Marsden (ed.). The Ashgate Research Companion to Religion and Conflict Resolution. Farnham: Ashgate.

RT, 2019. Putin, foreign interference in Venezuela's internal affairs grossly violates international law. $R T, 24$ January. Available at: <https://www.rt.com/ news/449630-putin-foreign-interference-in-venezuela/> [Accessed 14 February 2019].

Rodin, D., 2008. The moral inequality of soldiers: Why jus in bello asymmetry is half right. In: David Rodin and Henry Shue (eds.) Just and unjust warriors: the moral and legal status of soldiers. Oxford: Oxford University Press.

TASS, 2018. Lavrov castigates West for double standards on Kosovo, Mayotte. TASS, 9 November. Available at: <http://tass.com/world/1030138> [Accessed 15 February 2019]. 
The Ministry of Foreign Affairs of the Russian Federation, 2016. The Foreign Policy Concept of the Russian Federation. Available at: <http://www.mid.ru/en/ foreign_policy/official_documents/-/asset_publisher/CptICkB6BZ29/content/ id/2542248> [Accessed 14 February 2019].

Thakur, R., 2016. Ethics, international affairs and Western double standards. Asia \& The Pacific Policy Studies, 3(3), pp. 370-377.

Turner, S., 2003. The dilemma of double standards in U.S. human rights policy. Peace \& Change, 28(4), pp. 524-55.

Wodak, R., 2011. Critical discourse analysis. In: Ken Hyland and Brian Paltridge (eds.) The continuum companion to discourse analysis. London: Continuum.

Wood, T., 2018. Russia without Putin: money, power and the myths of the New Cold War. London: Verso. 